\title{
21. GEOCHEMICAL EVIDENCE FOR GAS HYDRATE IN SEDIMENT NEAR THE CHILE TRIPLE JUNCTION ${ }^{1}$
}

\author{
Philip N. Froelich, ${ }^{2}$ Keith A. Kvenvolden, ${ }^{3}$ Marta E. Torres, ${ }^{4}$ Amane Waseda, ${ }^{5}$ Borys M. Didyk, ${ }^{6}$ and Thomas D. Lorenson ${ }^{3}$
}

\begin{abstract}
Coring at ODPSites 859,860 , and 861 near the Chile Triple Junction failed to recover anticipated gas hydrate that was inferred to be present from two lines of geophysical evidence: pre-cruise observation of a weak to strong bottom simulating reflector (BSR) marking the predicted base of the gas-hydrate stability zone, and post-cruise interpretation of the velocity and resistivity logs at Site 859 that suggests the presence of gas hydrate. In contrast to other gas-hydrate occurrences observed during previous DSDP and ODP drilling, this Chile Margin sediment is very low in contents of total organic carbon ( $\mathrm{TOC}<0.5 \%$ ) and residual methane $\left(C_{1}\right)$, that are inconsistent with an in-situ source of methane for gas-hydrate formation. However, methane/ethane $\left(C_{1} / C_{2}\right)$ ratios $(>200)$ and $\delta^{13} \mathrm{C}_{1}$ values $(<-60 \%)$ show little evidence that the methane came from deeper thermogenic sources. Pore-fluid freshening does, however, suggest that gas hydrate is present, disseminated thinly and heterogeneously throughout the stability zone, and occupies less than $25 \%$ of the available pore space. The environment of the gas hydrate in sediment near the Chile Triple Junction has unique characteristics relative to known gas-hydrate occurrences elsewhere.
\end{abstract}

\section{INTRODUCTION}

Offshore from southern Chile lies a structurally complex region where the intersection of the Chile Ridge spreading center and the Chile Trench forms the Chile Triple Junction involving the interaction of three major tectonic plates. In a geophysical and geothermal study of this region, Cande et al. (1987) noted the presence of a bottomsimulating reflection (BSR) on marine seismic records obtained on an approximately east-west transect at latitude $45^{\circ} 55^{\prime} \mathrm{S}$ across the lower slope of the Chile Trench about $18 \mathrm{~km}$ north of the Chile Triple Junction. They inferred that this reflection marks the base of the zone of gas-hydrate stability and signals the occurrence of gas hydrate in shallow sediment of the forearc basin and accretionary complex adjacent to the axes of the Chile Ridge and Chile Trench (Fig. 1).

Gas hydrate is a solid substance composed of water molecules arranged in a rigid framework of cages, many of which are occupied by a molecule of gas, mainly methane. Because the stability of gas hydrate is controlled by specific thermobaric and chemical conditions, the zone of gas-hydrate stability can be predicted, and the base of this zone commonly correlates with a BSR. BSRs are high-amplitude, negative-polarity seismic reflections that subparallel the seafloor bathymetry at sub-bottom depths corresponding to the base of the gas-hydrate-stability zone (Shipley et al., 1979). BSRs are caused by an acoustic impedance change at an interface between hydratedcemented sediment of high acoustic velocity overlying low-velocity sediment lacking gas hydrate and/or containing free gas.

One objective of Leg 141 of the Ocean Drilling Program (ODP) was to examine the relations between the BSR and the inferred occurrence of gas hydrate. A unique aspect of this objective was that the proposed drilling represented the first attempt by the ODP to penetrate a reflecting horizon represented by the BSR. Previously, drilling through this horizon was considered to be unsafe because of the possible buildup of free gas beneath the zone of gas-hydrate occurrence (Ocean Drilling Program, 1986). Three sites $(859,860$,

\footnotetext{
'Lewis, S.D., Behrmann, J.H., Musgrave, R.J., and Cande, S.C. (Eds.), 1995. Proc. ODP, Sci. Results, 141: College Station, TX (Ocean Drilling Program).

${ }^{2}$ Lamont-Doherty Earth Observatory, Columbia University, Palisades, NY 10964, U.S.A. (Present address: School of Earth and Atmospheric Sciences, Georgia Institute of Technology, Atlanta, GA 30332-0340, U.S.A.)

${ }^{3}$ U.S. Geological Survey, Menlo Park. CA 94025 , U.S.A.

4 GEOMAR, D-2300 Kiel 14. Federal Republic of Germany.

5 JAPAX Research Center, Chiba 261, Japan.

${ }^{6}$ Empresa Nacional del Petróleo, Casilla 242, Concón, Chile.
}

and 861 ) were drilled along Line 745 (Fig. 1). The characteristics of the BSR at each site have been described by Bangs et al. (1993). At Site 859 in the toe of the accretionary complex, the BSR is a strong reflection at about $100 \mathrm{~m}$ below seafloor (mbsf). Along the lower slope, the BSR is semicontinuous and commonly strong. At Site 860 in the forearc basin, the BSR is strong at a depth of about $200 \mathrm{mbsf}$, and near Site 861 , it is weak at about $250 \mathrm{mbsf}$. Thus, the BSR along this transect becomes more shallow with increasing water depths, a trend opposite to what is usually observed. Increasing geothermal gradients toward the toe of the slope, which is close to the hot zero age crust of the spreading ridge, are postulated to be responsible for the observed trend in BSR depths (Cande et al., 1987).

Because gas hydrate is composed essentially of methane and water, the presence of these two substances provides geochemical evidence for gas-hydrate occurrence. Methane in association with gas-hydrate occurrence has been noted in deep-ocean drilling on Deep Sea Drilling Project (DSDP) Leg 76, Blake Outer Ridge (Kvenvolden and Barnard, 1983); DSDP Leg 84, slope of the Middle America Trench (Kvenvolden and McDonald, 1985); and Ocean Drilling Program (ODP) Leg 112, slope of the Peru-Chile Trench (Kvenvolden and Kastner, 1990). These studies provide a guide to methane distribution in sediment where gas hydrate is present.

During gas-hydrate formation and dissociation, pore-water geochemistry is altered. For example, when water molecules crystallize they exclude salt ions from the crystal structure. Measurements of the chlorinity of sediment pore waters where gas hydrate is present have invariably shown pore-water freshening (DSDP Leg 67, slope of Middle America Trench [Hesse and Harrison, 1981]; DSDP Leg 76 [Kvenvolden and Barnard, 1983; Jenden and Gieskes, 1983]; DSDP Leg 84 [Kvenvolden and McDonald, 1985; Hesse et al., 1985]; ODP Leg 112 [Kvenvolden and Kastner, 1990]). The observed chlorinity dilution is thought to result from the dissociation of gas hydrate, releasing freshwater during core recovery. Although pore-water freshening is not a unique geochemical signal for gas hydrate, wherever pore-water chlorinity decreases in the presence of large amounts of methane within the depth range of gas-hydrate stability, then gas hydrate is most likely present (Kvenvolden, 1993).

In this paper, we discuss the geochemistry of methane and pore water in sediment samples obtained from drill holes at Sites 859, 860, and 861 , where the holes penetrated the horizon marked by the BSR. We compare our results with information from previous ocean drilling and conclude that gas hydrate is present even though no gashydrate samples were recovered. At Site 859 (less so at Site 860 ), the 
intervals of markedly freshened pore fluids apparently demarcate sediment layers containing gas hydrate filling less than $25 \%$ of the pore volume.

\section{METHODS}

Geochemical measurements made aboard the research vessel JOIDES Resolution provided early evidence concerning gas-hydrate occurrence (Behrmann, Lewis, Musgrave, et al., 1992). Methods included the use of gas chromatography on gases extracted from small-volume $\left(\sim 3 \mathrm{~cm}^{3}\right)$ portions of sediment core and standard porefluid analytical methods on interstitial water squeezed from 6- to 10 -cm-long sections of sediment cores, and obtained from the in-situ Water Sampler Temperature Probe (WSTP) (Shipboard Scientific Party, 1992a). In addition, whole-round core segments, $5 \mathrm{~cm}$ long, were collected immediately as the core was retrieved on deck. Each segment was placed in a preweighed can, previously prepared with two septa-covered entry parts, and the weight of the sample was determined. Degassed water was added to the can leaving a $100 \mathrm{~cm}^{3}$ headspace; then, the can was sealed. The headspace was purged with helium, and the contents of the can were frozen. In a shorebased laboratory, the contents of the cans were thawed, the cans shaken to partition sediment gas into the headspace, and a portion of the resulting headspace gas was analyzed by gas chromatography. The results of analyses for methane, ethane, ethene, propane, propene, iso-butane and $n$-butane at Sites 859,860 , and 861 are reported here in microliters per liter $(\mu \mathrm{L} / \mathrm{L})$ of wet sediment (Table 1). These units are used because the results can be directly compared with those from some previous DSDP and ODP studies (Kvenvolden and Barnard, 1983; Kvenvolden and McDonald, 1985; Kvenvolden et al., 1989; Kvenvolden et al., 1990; Kvenvolden and Kastner, 1990). Wet weight of samples is also listed so that the gas concentrations can be converted to an alternative weight basis, if necessary.

\section{RESULTS}

Results of hydrocarbon-gas analyses not reported previously are listed in Table 1. Methane and other saturated-hydrocarbon gases to $n$-butane are commonly present. The unsaturated-hydrocarbon gases, ethene and propene, are also present in some samples with propene present in more samples than ethene. The most abundant hydrocarbon gases are methane $\left(C_{1}\right)$ and ethane $\left(C_{2}\right)$. The ranges of concentrations $(\mu \mathrm{L} / \mathrm{L})$, observed for these two compounds, and the range of $\mathrm{C}_{1} / \mathrm{C}_{2}$ ratios are as follows:

\begin{tabular}{lccc}
\hline & Site 859 & Site 860 & Site 861 \\
\hline $\mathrm{C}_{1}$ & 1400 to 88,500 & 50 to 41,400 & 7 to 116.000 \\
$\mathrm{C}_{2}$ & 1.2 to 23 & 0.30 to 180 & 0.03 to 103 \\
$\mathrm{C}_{1} / \mathrm{C}_{2}$ & 200 to 6500 & 47 to 52,100 & 170 to 9500 \\
\hline
\end{tabular}

Important geochemical considerations relative to the occurrence of gas (methane) hydrate include the concentration of methane in sediment, parameters related to the sources of methane gas, and inorganic parameters (chlorinity, sulfate, and alkalinity) of the pore water. Figures 2 through 4 summarize these geochemical considerations for Sites 859,860 , and 861 , respectively (Table 1; Shipboard Scientific Party, 1992b, 1992c, 1992d; Waseda et al., this volume). For comparison the same geochemical considerations for Peru Margin Sites 685 and 688 (Kvenvolden and Kastner, 1990; Kvenvolden et al., 1990) are shown in Figures 5 and 6 . The methane concentrations reported, which are a measure of the amount of residual methane that remains in the sediment after degassing during core recovery (Kvenvolden and Barnard, 1983), provide an approximate guide to in-situ methane concentrations. The $C_{1} / C_{2}$ ratios, $\delta^{13} C_{1}$ values, and total organic carbon (TOC) measurements are used to interpret possible sources of the methane. Chloride concentrations are affected by gas-hydrate dissociation during drilling and recovery (Hesse and Harrison, 1981) be- cause the release of freshwater effectively dilutes the pore-fluid (seawater) salt component. Alkalinities are a measure of the intensity of geochemical processes taking place in the sediment, including the reduction of carbon dioxide to methane (Kvenvolden and Kastner, 1990). Pore-water profiles of chloride, sodium, and potassium concentrations and salinity within the depth interval of predicted gashydrate stability at Chile Margin Sites 859 and 860 are shown in Figures 7 and 8 . These ions are the major salt constituents that are most likely to be affected by the dilution-freshening effect caused by gas-hydrate dissociation during drilling and core recovery.

\section{DISCUSSION}

Gas hydrate was inferred to be present in sediment at Sites 859 , 860 , and 861 on the basis of the BSR observed on marine seismic Line 745 (Cande et al., 1987). Although the BSR does not forecast the amount of gas hydrate present, it was nevertheless disappointing to observe that coring on Leg 141 at these sites through the BSR horizon did not prove the presence of gas hydrate through recovery of any gas-hydrate samples. However, lack of recovery of gas-hydrate samples does not mean that gas hydrate is absent. Previous ocean drilling has suggested that if gas hydrate is finely dispersed throughout the sediment, it is most likely to completely dissociate during the coring and recovery processes (Kvenvolden and Barnard, 1983; Kvenvolden and Kastner, 1990). Whenever the gas hydrate occurs as solid masses, recovery is much more probable (Kvenvolden and McDonald, 1985), especially if the section is rapidly rotary drilled. All previous recoveries of solid gas hydrate by the DSDP and ODP (albeit fortuitous) have occurred during rotary drilling, which apparently increases the probability of rapidly penetrating, coring, and recovering the solid gas hydrate before it can totally dissociate. During Leg 141, the upper intervals of predicted gas-hydrate occurrence were drilled and cored with the advanced piston corer and/or the extended core barrel systems. These upper-sediment intervals had poor drilling characteristics, slow advance of the drill bit, and very poor core recovery, These drilling characteristics decrease the probability of recovering solid gas hydrate that is likely to be dissociated both in-situ by drilling disturbances (fluid circulation) and upon core retrieval by pressure and temperature changes.

Because gas hydrate was not recovered on Leg 141 all evidence for gas-hydrate occurrence, both geophysical and geochemical, is inferential. To assess the geochemical evidence, we compare our results with those obtained during ODP Leg 112 at Sites 685 and 688 (Figs. 5 and 6) where gas-hydrate samples were recovered on the landward slope of the Peru-Chile Trench off the coast of Peru (Kvenvolden and Kastner, 1990). Thus, these Leg 112 sites are located on the same trench system as the Leg 141 sites but separated by a distance of about $3900 \mathrm{~km}$. The Leg 112 results generally conform to the in-situ model of gas-hydrate formation (Claypool and Kaplan, 1974), which assumes that methane is generated microbially from organic matter within the zone of gas-hydrate stability. The two localities, however, differ widely in the biogenic makeup of their sediment: the Peru Margin has an organic-rich, upwelling regime, whereas the Chile Margin is a very low productivity area.

\section{Methane}

Where gas hydrates have been previously found, distributions of methane concentration with depth commonly show a distinctive profile characterized by a rapid increase with depth within the uppermost $100 \mathrm{~m}$ of sediment and maximum concentrations approaching about $100,000 \mu \mathrm{L} / \mathrm{L}$ (Figs. 5 and 6). Below depths of maximum concentrations, methane abundances remain high, exceeding $1000 \mu \mathrm{L} / \mathrm{L}$ and commonly $10,000 \mu \mathrm{L} / \mathrm{L}$. The methane-distribution profile at Site 859 (Fig. 2) is similar to those from Leg 112 (Figs. 5 and 6) except that the methane concentrations at Site 859 are generally lower. The methane distribution profiles at Sites 860 and 861 (Figs. 3 and 4) do not show 
Table 1. Concentrations of residual methane and other hydrocarbon gases in sediment from Leg 141 Sites 859,860 , and 861 .

\begin{tabular}{|c|c|c|c|c|c|c|c|c|c|c|c|}
\hline \multirow{2}{*}{$\begin{array}{l}\text { Core, section, } \\
\text { interval }(\mathrm{cm})\end{array}$} & \multirow{2}{*}{$\begin{array}{l}\text { Depth } \\
\text { (mbsf) }\end{array}$} & \multirow{2}{*}{$\begin{array}{l}\text { Wet wt. } \\
\text { (g) }\end{array}$} & Methane & Ethane & Ethene & Propane & Propene & $i$-Butane & n-Butane & \multirow[b]{2}{*}{$\mathrm{C}_{1} / \mathrm{C}_{2}$} & \multirow[b]{2}{*}{ Comment } \\
\hline & & & \multicolumn{7}{|c|}{ ( $\mu \mathrm{L} / \mathrm{L}$ wet sediment) } & & \\
\hline \multicolumn{12}{|l|}{ 141-859A- } \\
\hline $2 \mathrm{H}-3,145-150$ & 5.65 & 95.40 & 88.500 & 5.13 & ND & 0.89 & 0.03 & 0.26 & 0.12 & 17,200 & \\
\hline $2 \mathrm{H}-3,145-150$ & 21.15 & 93.10 & 5,600 & 2.21 & ND & 0.23 & ND & 0.00 & 0.00 & 2,600 & \\
\hline $6 \mathrm{H}-2,5-10$ & 36.25 & 94.60 & 16,500 & 4.36 & ND & 0.35 & 0.14 & 0.58 & 0.90 & 3,800 & \\
\hline $13 \mathrm{X}-1.95-100$ & 78.95 & 96.50 & 5,100 & 1.51 & ND & 0.17 & 0.06 & 0.25 & 0.09 & 3,400 & \\
\hline $2 \mathrm{R}-2.140-145$ & 64.50 & 93.20 & 8.100 & 1.24 & ND & 0.13 & ND & 0.18 & 0.03 & 6.500 & \\
\hline $10 \mathrm{R}-2.145-150$ & 199.65 & 94.00 & 26,600 & 12.60 & ND & 1.30 & 0.03 & 0.82 & 0.16 & 2,100 & \\
\hline $13 R-5.145-150$ & 233.05 & 94.40 & 12,000 & 18.90 & ND & 9.82 & 0.18 & 7.95 & 1.70 & 640 & \\
\hline $16 R-2,135-140$ & 254.45 & 94.00 & 6.800 & 5.75 & ND & 3.90 & 0.03 & 3.62 & 0.55 & 1,200 & \\
\hline $19 R-3.145-150$ & 287.95 & 93.90 & 1.900 & 6.96 & ND & 5.08 & 0.11 & 4.68 & 1.66 & 280 & Septa leak \\
\hline $22 R-1.118-123$ & 313.18 & 94.70 & 4.200 & 20.60 & ND & 14.80 & 0.09 & 8.53 & 1.03 & 200 & \\
\hline $25 \mathrm{R}-3,135-140$ & 343.90 & 93.90 & 12.500 & 12.30 & ND & 8.64 & 0.08 & 8.15 & 0.79 & 1.000 & \\
\hline $28 R-4.145-150$ & 376.05 & 94.30 & 16.600 & 23.40 & ND & 20.20 & ND & 22.80 & 1.60 & 720 & \\
\hline $32 \mathrm{R}-1.85-90$ & 409.45 & 93.70 & 1.400 & 2.37 & ND & 3.08 & 0.15 & 3.71 & 0.97 & 590 & \\
\hline $35 R-1,145-150$ & 439.05 & 93.70 & 13.700 & 11.80 & ND & 9.80 & ND & 14.10 & 1.41 & 1.200 & \\
\hline $38 R-2,10-15$ & 468.00 & 93.00 & 12,600 & 16.30 & ND & 11.80 & 15.00 & 1.11 & 0.63 & 770 & \\
\hline \multicolumn{12}{|l|}{$141-860 \mathrm{~A}-$} \\
\hline IH-5, 140-145 & 7.40 & 96.40 & 420 & 0.75 & ND & 0.43 & 0.18 & 0.00 & 0.08 & 570 & \\
\hline $2 \mathrm{H}-3.140-145$ & 5.80 & 93.90 & 51 & 1.10 & 0.75 & 0.74 & 0.28 & 0.34 & 0.92 & 50 & \\
\hline $4 \mathrm{H}-3,140-145$ & 24.80 & 95.20 & 8.900 & 0.47 & ND & 0.21 & 0.28 & 0.11 & 0.15 & 19.000 & \\
\hline $6 \mathrm{H}-5,135-140$ & 46.75 & 93.40 & 15.200 & 0.29 & ND & 0.45 & 0.03 & 0.00 & 0.00 & 52.000 & \\
\hline $12 X-2,135-140$ & 90.55 & 93.70 & 3,700 & 0.29 & ND & 0.30 & 0.38 & 0.60 & 0.78 & 12.400 & \\
\hline $14 X-1.135-140$ & 100.45 & 93.10 & 8.500 & 0.32 & ND & 0.20 & 0.38 & 0.11 & 0.17 & 26.100 & \\
\hline $16 X-2,135-140$ & 119.65 & 94.50 & 18.600 & 2.04 & 1.14 & 0.65 & 0.34 & 0.21 & 0.21 & 9,100 & \\
\hline $19 X-4,135-140$ & 142.95 & 93.80 & 10.500 & 2.15 & 0.80 & 0.36 & 0.21 & 0.18 & 0.12 & 4.00 & \\
\hline $22 \times-1,135-140$ & 166.45 & 96.20 & 67 & 0.03 & ND & 0.07 & 0.07 & 0.07 & 0.12 & 2.300 & Lid leak \\
\hline $24 X-1.135-140$ & 185.75 & 93.60 & 15,000 & 10.40 & ND & 0.32 & 0.14 & 0.06 & 0.44 & 1.400 & \\
\hline $29 X-1,135-140$ & 234.15 & 93.20 & 18.800 & 33.70 & ND & 0.43 & 0.19 & 0.53 & 1.09 & 560 & \\
\hline $31 X-2,135-140$ & 254.75 & 93.60 & 32.500 & 124.00 & ND & 3.37 & 0.33 & 2.62 & 1.26 & 260 & \\
\hline $33 X-1.135-140$ & 272.65 & 96.00 & 8,800 & 45.60 & 0.46 & 1.44 & 0.42 & 0.93 & 0.49 & 160 & \\
\hline $35 X-1.145-150$ & 290.55 & 93.60 & 12.500 & 49.70 & ND & 1.39 & 0.29 & 1.55 & 0.36 & 250 & \\
\hline $38 \mathrm{X}-1.15-20$ & 320.69 & 93.70 & 14,800 & 83.60 & ND & 2.86 & 0.17 & 2.55 & 0.95 & 180 & \\
\hline $41 X-5,126-131$ & 355.30 & 95.30 & 13,400 & 94.40 & ND & 3.16 & 0.16 & 2.79 & 0.55 & 140 & \\
\hline $46 X-1,99-104$ & 387.59 & 93.80 & 17,000 & 45.80 & ND & 1.96 & 0.13 & 3.96 & 1.60 & 370 & \\
\hline $48 \times-2,34-39$ & 407.84 & 94.10 & 83 & 0.81 & 0.26 & 0.27 & 0.23 & 0.65 & 0.71 & 100 & Septa leak \\
\hline $50 \times-3.60-65$ & 428.90 & 94.30 & 21.000 & 38.30 & ND & 2.11 & 0.44 & 3.70 & 0.62 & 550 & \\
\hline $53 X-2,130-135$ & 450.40 & 93.70 & 10.000 & 41.90 & ND & 4.35 & 0.25 & 6.25 & 1.98 & 240 & \\
\hline $58 \mathrm{X}-2,135-140$ & 495.65 & 93.50 & 41.400 & 162.00 & ND & 9.17 & 0.00 & 7.63 & 0.98 & 260 & \\
\hline $60 X-2,75-80$ & 514.25 & 93.90 & 37,900 & 137.00 & ND & 8.68 & 0.12 & 8.02 & 0.82 & 280 & \\
\hline $62 X-2.135-140$ & 535.25 & 95.80 & 19.000 & 97.50 & ND & 10.30 & 0.46 & 10.70 & 1.05 & 200 & \\
\hline $66 X-2.135-140$ & 570.85 & 93.70 & 31.200 & 179.00 & ND & 21.30 & 0.21 & 20.00 & 1.60 & 180 & \\
\hline \multicolumn{11}{|l|}{ 141-861B- } & \\
\hline \multicolumn{12}{|l|}{$141-861 \mathrm{C}$} \\
\hline $2 \mathrm{H}-3,140-145$ & 7.40 & 93.20 & 250 & 0.54 & 0.30 & 0.30 & 0.16 & 0.07 & 0.06 & 470 & \\
\hline $6 \mathrm{H}-3,140-145$ & 45.40 & 93.50 & 5,300 & 0.56 & ND & 0.17 & 0.03 & 0.03 & 0.03 & 9.500 & \\
\hline $8 \mathrm{H}-3,135-140$ & 64.35 & 94.10 & 3.200 & 0.55 & ND & 0.15 & ND & 0.07 & 0.03 & 5,800 & \\
\hline $12 X-1,135-140$ & 91.45 & 93.50 & 14.000 & 3.22 & ND & 0.22 & ND & 0.11 & 0.00 & 4,400 & \\
\hline $14 X-1135-140$ & 110.75 & 94.30 & 13.900 & 7.32 & ND & 0.34 & ND & 0.00 & 0.03 & 1.900 & \\
\hline $16 X-3,135-140$ & 133.25 & 93.20 & 10.400 & 8.74 & ND & 0.32 & 0.03 & 0.18 & 0.10 & 1,200 & \\
\hline $18 X-3,135-140$ & 152.35 & 93.10 & 11.900 & 11.70 & ND & 0.21 & ND & 0.00 & 0.00 & 1.000 & \\
\hline $21 X-1,135-140$ & 171.55 & 94.70 & 20.000 & 26.00 & ND & 0.29 & ND & 0.13 & 0.06 & 770 & \\
\hline $25 X-4,135-140$ & 214.75 & 93.50 & 23,100 & 41.80 & ND & 0.33 & 0.29 & 0.14 & 0.17 & 550 & \\
\hline $28 \times-4,140-145$ & 233.59 & 94.90 & 14.700 & 88.30 & 0.52 & 0.83 & 0.29 & 0.53 & 0.29 & 170 & \\
\hline $31 \times-2,140-145$ & 251.15 & 94.20 & 15.700 & 91.70 & ND & 0.92 & ND & 0.75 & 0.31 & 170 & \\
\hline $33 \mathrm{X}-1.140-145$ & 267.95 & 95.70 & 9.900 & 46.80 & ND & 0.55 & 0.03 & 0.33 & 0.16 & 210 & \\
\hline $36 X-2,140-145$ & 298.45 & 95.40 & 13,800 & 70.20 & ND & 0.94 & 0.15 & 0.53 & 0.13 & 200 & \\
\hline $39 X-2,140-145$ & 326.17 & 94.30 & 21.100 & 33.60 & ND & 0.56 & 0.40 & 0.70 & 0.44 & 630 & \\
\hline 141-861D. & & & & & & & & & & & \\
\hline $2 \mathrm{R}-1.145-150$ & 353.35 & 94.80 & 21,300 & 103.00 & ND & 0.98 & 0.15 & 1.03 & 0.18 & 207 & \\
\hline $7 \mathrm{R}-2,120-124$ & 402.80 & 95.50 & 49,600 & 76.10 & ND & 0.63 & 0.14 & 1.03 & 0.33 & 651 & \\
\hline $9 R-1.130-135$ & 421.00 & 94.20 & 16,600 & 21.30 & ND & 0.29 & ND & 0.29 & 0.03 & 777 & \\
\hline $11 R-1,105-110$ & 439.85 & 94.80 & 12.900 & 22.00 & ND & 0.32 & ND & 0.20 & 0.16 & 587 & \\
\hline $13 R-2,78-83$ & 460.38 & 94.40 & 116.000 & 73.50 & ND & 1.27 & 0.17 & 0.13 & 0.13 & 1.576 & \\
\hline $16 \mathrm{R}-1,135-140$ & 487.35 & 93.90 & 27.500 & 14.30 & ND & 0.38 & 0.46 & 0.10 & 0.19 & 1.920 & \\
\hline
\end{tabular}

Notes: ND = not detected. Measurements from the Marine Organic Geochemistry Laboratory of the U.S.G.S. in Menlo Park, Calif.

a maximum near the surface, but other values are comparable to those in the Leg 112 profiles (Figs. 5 and 6). However, we cannot rule out the possibility that the poor drilling characteristics and concomitant sediment disturbances that occurred during drilling and coring at Sites 859,860 , and 861 permitted more extensive degassing of the sediments before shipboard processing, thus lowering the apparent methane concentrations.

\section{$\mathrm{C}_{1} / \mathrm{C}_{2}$ Ratios and $\delta^{13} \mathrm{C}_{1}$}

Although $\mathrm{C}_{2}$ concentrations are generally less than $0.1 \%$ of the hydrocarbon gases present in most oceanic sediment, the $C_{1} / C_{2}$ ratio commonly decreases exponentially with depth (Claypool and
Kvenvolden, 1983). With some exceptions, this same trend was observed in the results from Leg 112 (Figs. 5 and 6) and Leg 141 (Figs. $2-4)$, although the Leg 141 results vary somewhat in detail. For example, at Sites 859 and 861 , the $C_{1} / C_{2}$ ratios are always less than 10,000 , whereas at Site 860 , the maximum $C_{1} / C_{2}$ ratio is 52,100 , comparable to those ratios at Sites 685 and 688. Also, at depth in the sediment, the Leg 141 results do not conform to an exponentially decreasing trend, suggesting that, in addition to the hydrocarbon gases generated in situ, an unidentified source may contribute minor amounts of hydrocarbons to the sediment.

The isotopic composition of methane $\left(\mathrm{C}_{1}\right)$ in the hydrocarbon gases of oceanic sediment provides good evidence for the origin of the methane (Rice and Claypool, 1981). Values of $\delta^{13} \mathrm{C}_{1}$ in oceanic 


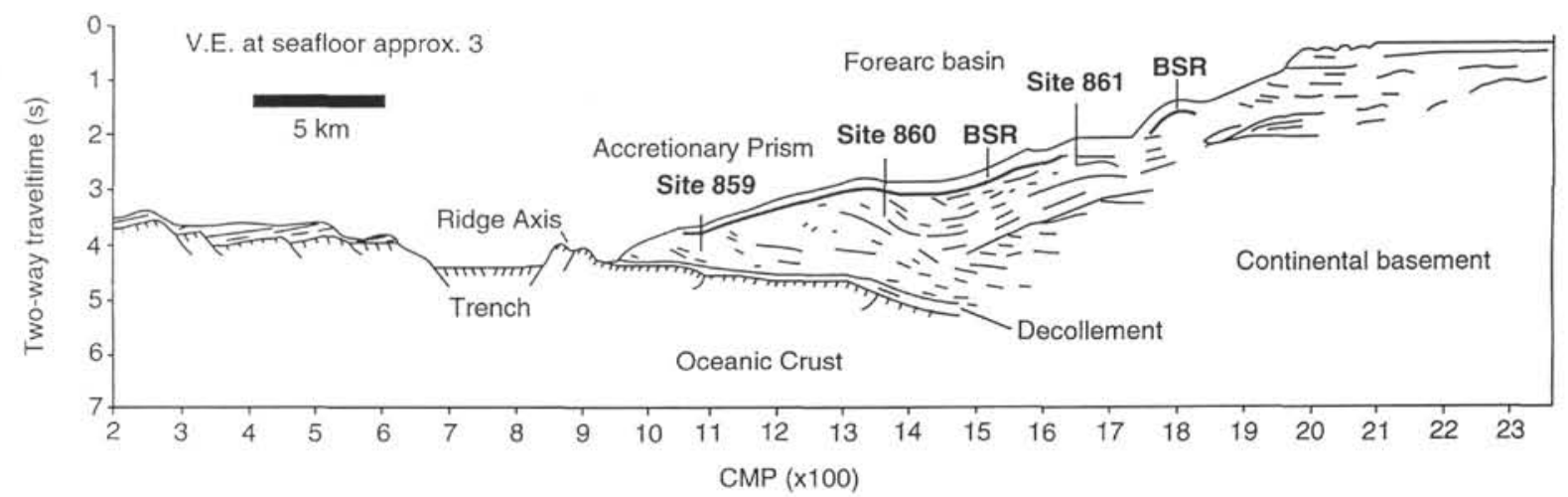

Figure 1. Line-drawing interpretation of seismic Line 745 showing the location of Sites 859,860 , and 861 in the accretionary complex and forearc basin of the lower slope of the Chile Margin. BSR $=$ the bottom-simulating reflector marking the inferred base of gas hydrate. CMP = the common mid-point of the seismic record. Modified from Bangs et al. (1992).

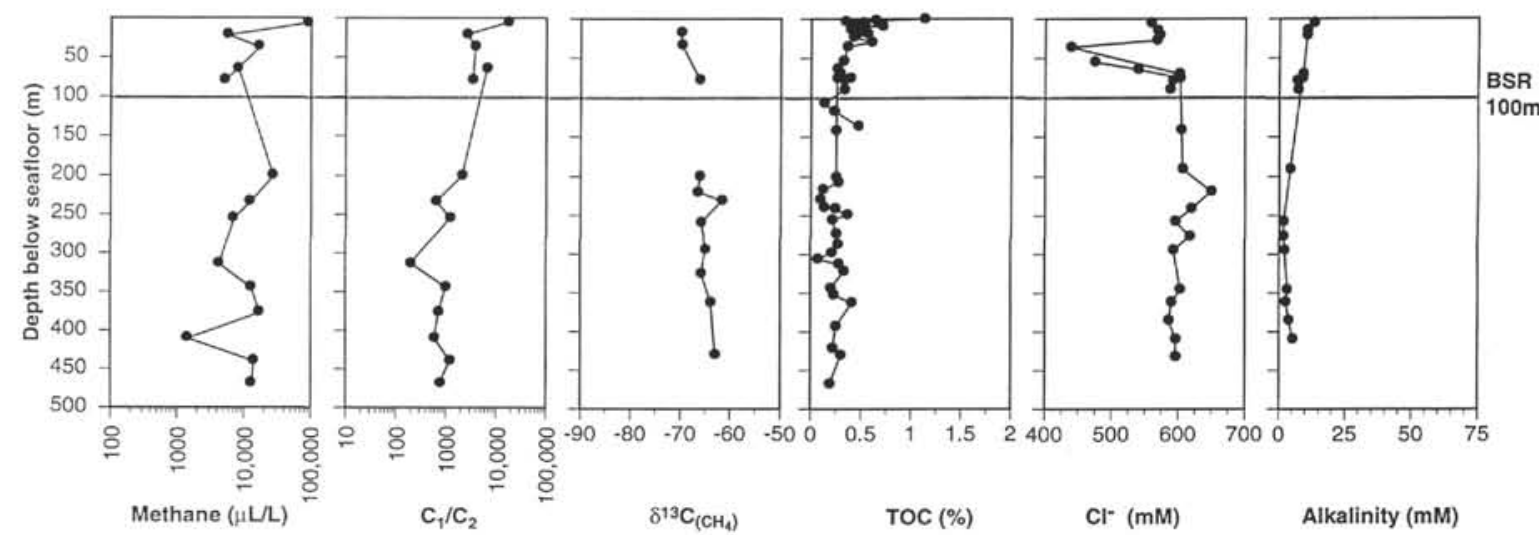

Figure 2. Vertical profiles of organic geochemical parameters at Site 859.

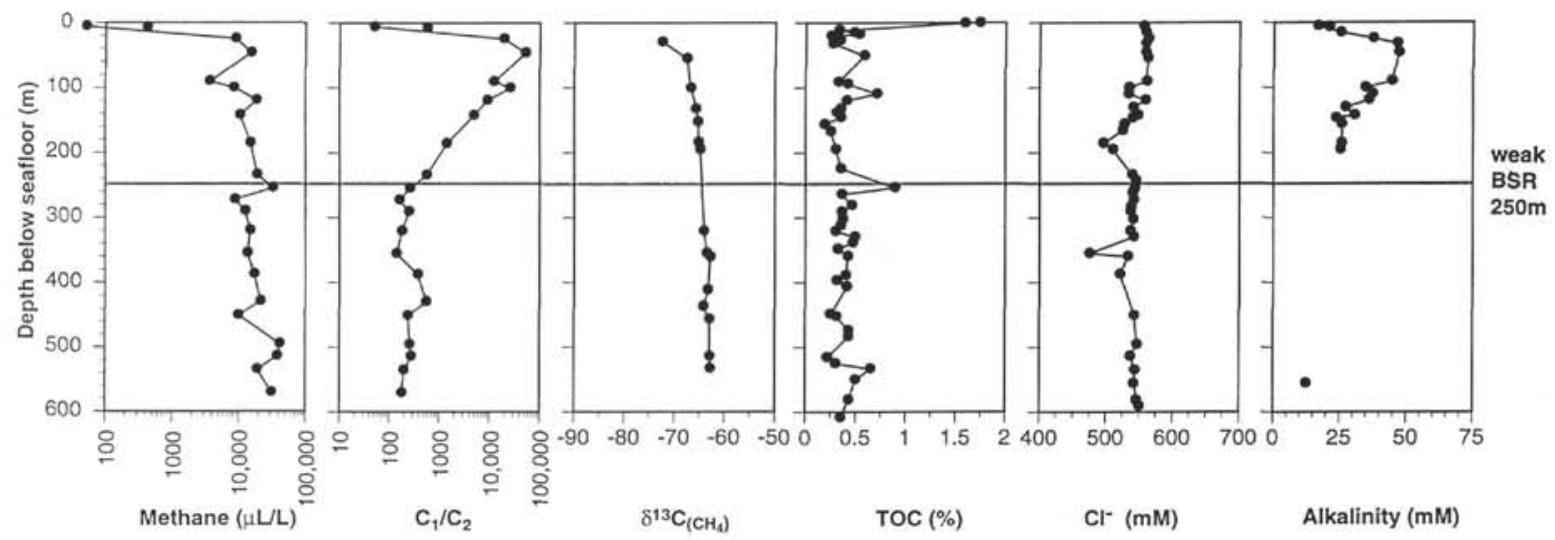

Figure 3. Vertical profiles of organic geochemical parameters at Site 860.

sediment commonly range from about $-90 \%$ to $-50 \%$, values characteristic of microbially derived methane from natural sources (Fuex, 1977). The $\delta^{13} \mathrm{C}_{1}$ values from Legs 112 and 141 (Figs. 2-6) all fall within this range, supporting the idea of microbial methane generation in sediment offshore both Peru and Chile. In all samples, the $\delta^{13} C_{1}$ values are lighter near the surface and become heavier with depth, a trend most likely resulting from the effects of microbial methanogenesis (Claypool and Kvenvolden, 1983), wherein carbon dioxide serves as the source for methane.

The trends of $C_{1} / C_{2}$ ratios and $\delta^{13} C_{1}$ values observed here are consistent with the occurrence of gas hydrate formed mainly by in- situ microbial processes taking place within the zone of gas-hydrate stability. These trends, however, do not prove the presence of gas hydrate because they can be expected wherever microbial methane generation takes place in oceanic sediment.

\section{Total Organic Carbon}

If the in-situ model for gas-hydrate formation is correct, then the amount of metabolizable organic matter in the sediment is critical to the process. Methane production requires a minimum of about $0.5 \%$ TOC (Claypool and Kaplan, 1974). This requirement is well satisfied 


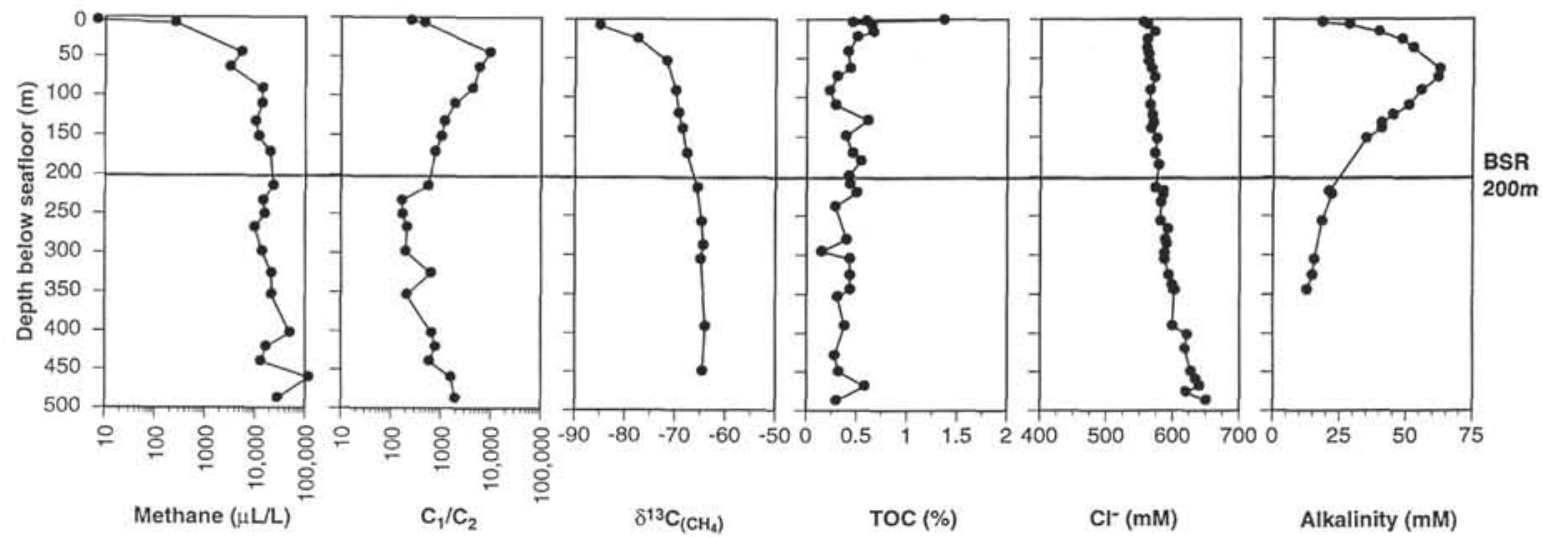

Figure 4. Vertical profiles of organic geochemical parameters at Site 861.

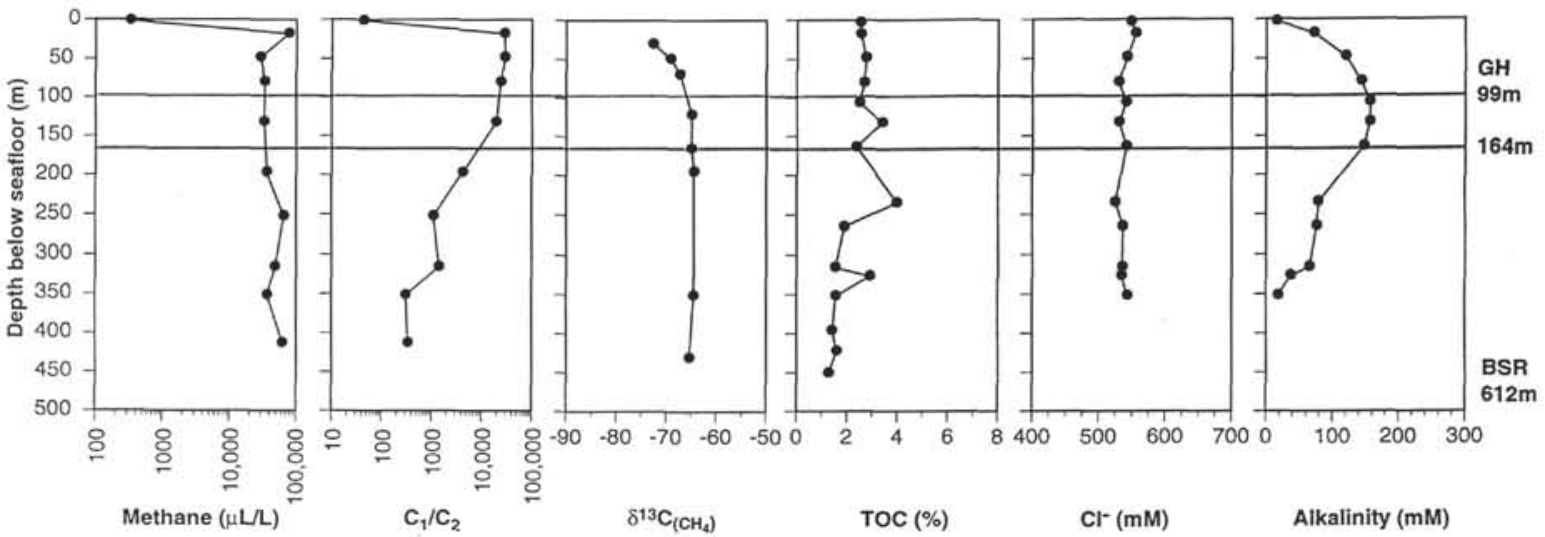

Figure 5. Vertical profiles of organic geochemical parameters at Leg 112 , Site 685 . GH = gas hydrate.

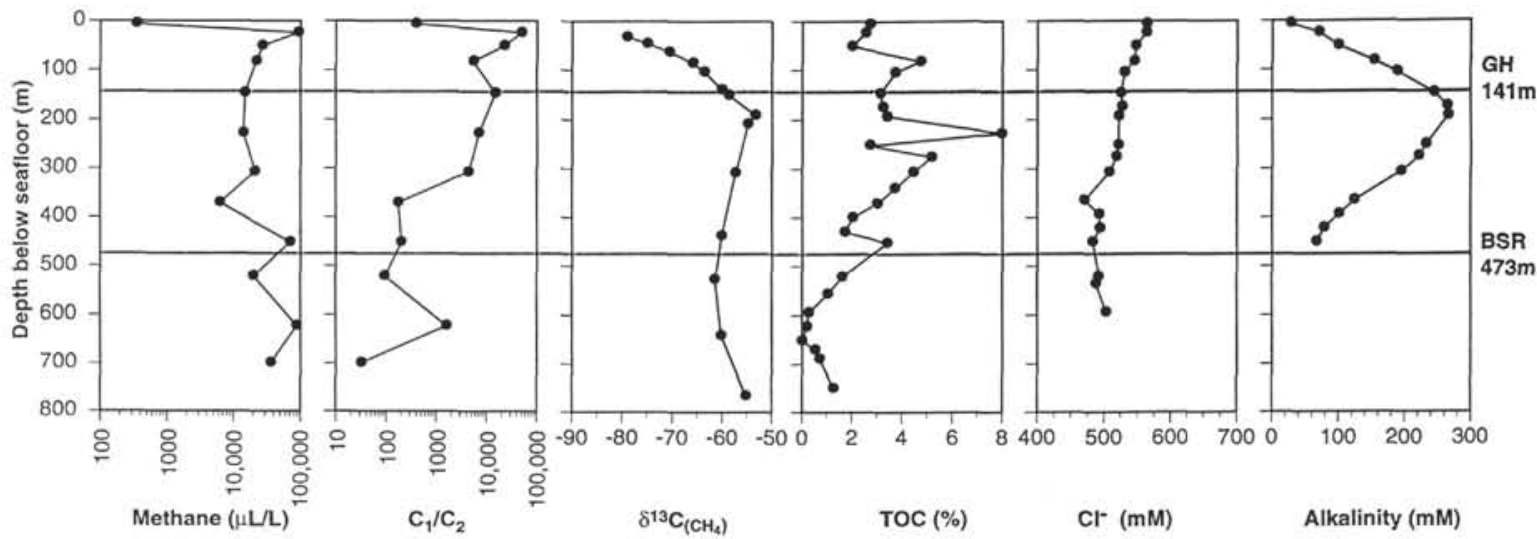

Figure 6. Vertical profiles of organic geochemical parameters at Leg 112, Site 688. GH = gas hydrate.

at Sites 685 and 688 (Figs. 5 and 6) offshore from Peru, where modern coastal upwelling systems provide a rich source of organic matter. At Site 685 , TOC ranges from $1.27 \%$ to $3.98 \%$, and at Site 688 , above the BSR, from $1.99 \%$ to $7.97 \%$.

In contrast, TOC values in sediment at Sites 859,860 , and 861 are generally less than $0.5 \%$ (Figs. $2-4$ ). Thus, in terms of microbial methane generation for gas-hydrate formation, the sediment is marginal at best. The presence of gas hydrate where TOC values are so low may require an accumulated source of methane beyond that generated contemporaneously in situ. The geochemical evidence, based on the amount of methane, $\mathrm{C}_{1} / \mathrm{C}_{2}$ ratios, and $\delta^{13} \mathrm{C}_{1}$ values, however, does not clearly indicate a significant secondary, nonmicrobial source of methane in sediment at these Leg 141 sites.
The conundrum presented by the organic geochemical results leads to speculation that the methane in gas hydrate in sediment of the Chile Margin is relict, from organic-rich sources that were not drilled and may have already been subducted. The oldest sediment recovered during Leg 141 is early Pliocene, whereas possibly organic-rich Miocene sediment is absent.

\section{Pore-water Chemistry}

As Hesse and Harrison (1981) first noted, the chlorinity of pore water in sediment associated with gas-hydrate occurrence shows freshening, with chlorinities measuring less than that of seawater $(\sim 559 \mathrm{mM})$. At Peru Margin Sites 685 and 688 , where gas hydrate was 


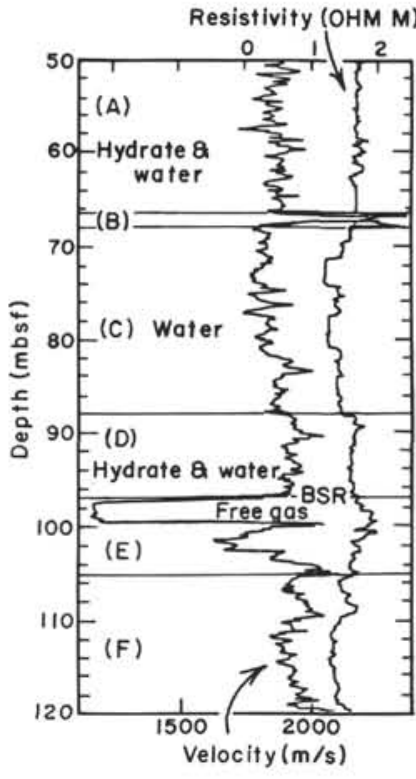

Logs
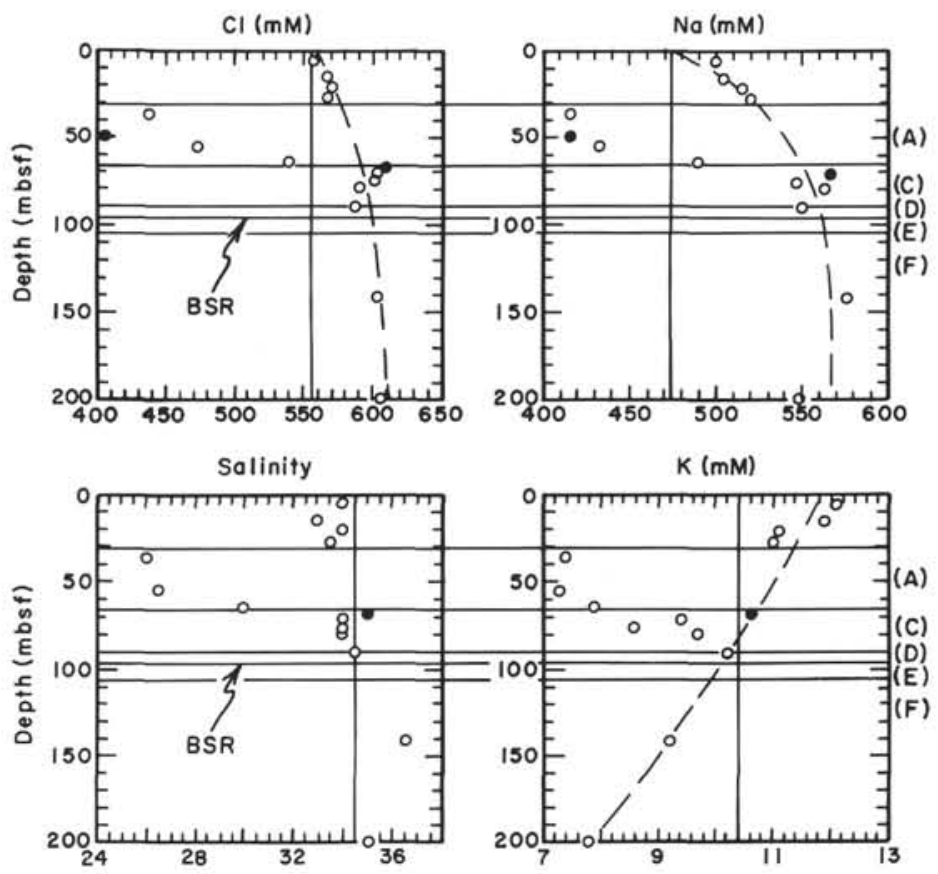

Pore - water chemistry

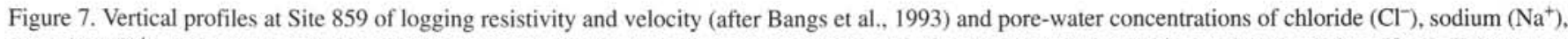
potassium $\left(\mathrm{K}^{+}\right)$, and salinity. The bottom-hole assembly for the logging runs was positioned at $47 \mathrm{mbsf}$, and the logged interval begins below $50 \mathrm{mbsf}$. The upper hydrated interval (A), between about 30 and 68 mbsf, was recognized by freshened pore fluids from both in-situ WSTP samples (solid symbols) and recovered core samples squeezed aboard ship (open symbols). The lower hydrated interval (D), between about 88 and 98 mbsf, was not recovered, nor was there recovery in the 30-m-thick interval immediately below the BSR. Vertical solid lines $=$ seawater concentration for a bottom-water salinity of 34.5 . Dashed lines $=$ inferred "background" diffusion gradients predicted in the absence of the hydrate-induced "freshened" zone.

observed, chlorinity decreases with depth (Figs. 5 and 6). At Site 685, the decrease is slight, whereas at Site 688 it is much greater. However, these holes did not penetrate the base of the gas-hydrate-stability zone (BSR), and thus they could not confirm the absence of pore-fluid freshening below the BSR where gas hydrate is inferred to be absent.

At Chile Margin Sites 859 and 860, chlorinity profiles differ from those obtained offshore from Peru and in other regions of gas-hydrate occurrence (Figs. 2 and 3). At Site 859 , there is a $15 \%$ to $25 \%$ freshening in the interval between 30 and $68 \mathrm{mbsf}$, as observed in chloride, sodium, and potassium concentrations and salinity (Fig. 7). This interval corresponds to the "upper" hydrate layer (labeled A) inferred from well-logging records (Bangs et al., 1993). Apparently, the dissociation of gas hydrate has artificially freshened the formation fluids in the cores recovered from the gas-hydrate interval. Alternatively, these abrupt changes might represent in-situ processes, but only if destabilization of the gas hydrate (thermally or tectonically) and freshwater release occurred within very recent geologic time; otherwise, the sharp features should have been obliterated by diffusion of fluids. In addition, this freshened interval occurs in the midst of broader gradients of downward-increasing sodium and chloride concentrations, and downward-decreasing potassium concentrations (Figs. 7 and 8). These gradients may reflect the in-situ (undisturbed) gradients. It is unlikely that these abrupt changes in sodium, chloride, and potassium concentrations are the result of local in-situ chemical reactions, although the long-scale gradients are probably imparted by mineral-hydration/ dehydration reactions at depth (Zheng et al., this volume). These deeper gradients, which extend to the total drilled depth at Sites 859 and 860 , may or may not be related to gas-hydrate occurrence.

Two successful WSTP deployments were made at Site 859. One, in the middle of the upper gas-hydrate zone (labeled A, Fig. 7) clearly displays freshening by about $25 \%$, suggesting either (1) that the formation fluid is freshened in-situ, or (2) that dissociation of the gas hydrate occurs at the bottom of the hole about $1 \mathrm{~m}$ ahead of the drill bit during the period between core retrieval and WSTP deployment, or (3) that the thermal pulse upon probe insertion and the pressure drop around the probe tip upon fluid extraction induced in-situ gashydrate decomposition. We favor the latter explanation. The WSTP overflow chamber, flushed with nitrogen and evacuated before deployment, contained an overpressured gas (presumably methane) upon recovery. A second successful WSTP deployment recovered from the nonhydrated interval (labeled C, Fig. 7) clearly displays a pore-fluid chemistry consistent with the squeezed pore-fluid data (Fig. 7) and with the absence of gas hydrate in this interval to cause dissociation freshening. This interval $(\mathrm{C})$, between 68 and $81 \mathrm{mbsf}$, is clearly sandwiched between the BSR ( $\sim 98 \mathrm{mbsf})$ and the upper gashydrate layer (A) at about 30 to 68 mbsf.

The shipboard drillers' records for Site 859 also contain clues that correlate with the logging and pore-fluid observations. First, no cores were recovered in the lower gas-hydrate zone (labeled D, Fig. 7) between about 88 and $98 \mathrm{mbsf}$, or in the region below the BSR. Bangs et al. (1993) have inferred that the gas-hydrate content of interval (D) was higher (maximum of $18 \%$ of available pore space) than in the upper gas-hydrate interval (less than 10\%). Second, a "hard layer" was recognized by the drillers at about $67 \mathrm{mbsf}$. This layer is clearly visible in the logging record (Fig. 7) as a high-velocity, highresistivity interval (B) that forms the base of an upper hydrated interval (A). This layer was not recovered. Unsubstantiated shipboard interpretations suggested a carbonate stringer (Shipboard Scientific Party, 1992b), but whether the layer is a solid gas hydrate or an authigenic carbonate "floor" to the gas-hydrate layer is unknown. Third, the weight on the drill bit dropped quickly as the drill advanced through the 98-mbsf level between intervals (D) and (E), suggesting that the $1 \%$ to $2 \%$ "free gas," inferred to exist below the BSR (Bangs et al., 1993), was represented by an easily penetrated, but unrecov- 
ered, sedimentary interval. There was no indication that this interval was overpressured.

Interpretation of the well logs, drilling records, and pore-fluid chemistry in the hydrated layer (labeled A, Fig. 7) of Site 859 is consistent with a finely disseminated gas hydrate that occupies a small fraction of the available pore space. Bangs et al. (1993) have inferred from compressional-wave velocities that about $10 \%$ to $18 \%$ of the pore space is occupied by solid gas hydrate. Pore-fluid chemistry suggests a maximum freshening of $24 \%$ chloride, $12 \%$ sodium, and $29 \%$ potassium concentrations, and $25 \%$ salinity, which are consistent with interpretations based on well logs. This evidence further suggests that gas hydrate occurs in Chile Margin sediment at Site 859 in disseminated rather than massive form. If massive gas hydrate had been found, the pore-fluid chemistry would have shown much greater water freshening.

The seismic Line 745 across Site 860 (Fig. 1) displays a conspicuous BSR at about $200 \mathrm{mbsf}$ that was inferred to represent the base of the gas-hydrate stability zone (Bangs et al., 1993). Pore-water profiles at Site 860 (Fig. 8) show some evidence for freshening in the 20- to $50-\mathrm{m}$ interval immediately above the BSR. Site 860 was not successfully logged, and no solid gas hydrate was recovered. Thus, evidence for the presence of gas hydrate is less convincing here than at Site 859. If the freshening at Site 860 is the result of dissociation of gas hydrate, we estimate that less than $10 \%$ of the pore volume between 170 and $200 \mathrm{mbsf}$ is filled with gas hydrate. Similar to the coring results obtained at Site 859, the interval through the BSR and immediately below at Site 860 was not recovered. Only a weak BSR was observed at Site 861 at about $250 \mathrm{mbsf}$, and pore-water freshening did not occur in sediment above the BSR (Fig. 4). This information, together with the organic geochemical data, suggests that gas hydrate is absent at Site 861 .

Alkalinities are included here for the purpose of comparison only. Record high alkalinities were observed at Sites 685 and 688 (Figs. 5 and 6) and at sites on the inner slope of the Middle America Trench (Harrison et al., 1982), where gas hydrate was recovered. Thus, higher alkalinities may be characteristic of gas-hydrate occurrence. Although significant alkalinity occurs in pore water at Sites 860 and 861 (Fig. 3 and 4), the alkalinity observed at Site 859 is much lower (Fig. 2). The range of alkalinity expected in sediment associated with gas-hydrate occurrence has never been defined, although very high alkalinity and gas-hydrate occurrence appear to correlate.

One interesting, unexpected, and unique aspect of the gas hydrate at Site 859 is an inferred "double layer." Gas-hydrate layers (A and D, Fig. 7) are separated by an intervening interval apparently devoid of gas hydrate. The upper layer (A) is floored by a "hard layer," whereas the lower layer (D) is floored by a more "typical" BSR ("free gas" below). Without additional evidence that may have been obtained if gas hydrate had been recovered, we can only speculate whether this double layer is a steady-state, thermobaric feature induced by small differences in the vertical thermal structure, or may reflect a recent (non-steady state) upward migration of the base of the gas-hydrate stability zone induced by recent tectonic uplift and warming as this accretionary wedge approaches the ridge axis.

\section{SUMMARY}

Although gas-hydrate samples were not recovered during drilling at Leg 141 Sites 859, 860, and 861, geochemical and geophysical evidence suggests that gas hydrate is present at least at Site 859. The base of the gas hydrate occurs at about $100 \mathrm{mbsf}$ and is marked by a strong BSR. The minimum chloride concentrations, due to pore-fluid freshening upon gas-hydrate dissociation, occur some $50 \mathrm{~m}$ above the BSR. The characteristics of the inferred gas hydrate at this site are unique relative to known gas-hydrate occurrences elsewhere. Correlation of pore-water parameters and well-log responses suggests that the gas hydrate occurs in two stratigraphic intervals, each with distinctive pore-water freshening and separated by an interval without pore-water

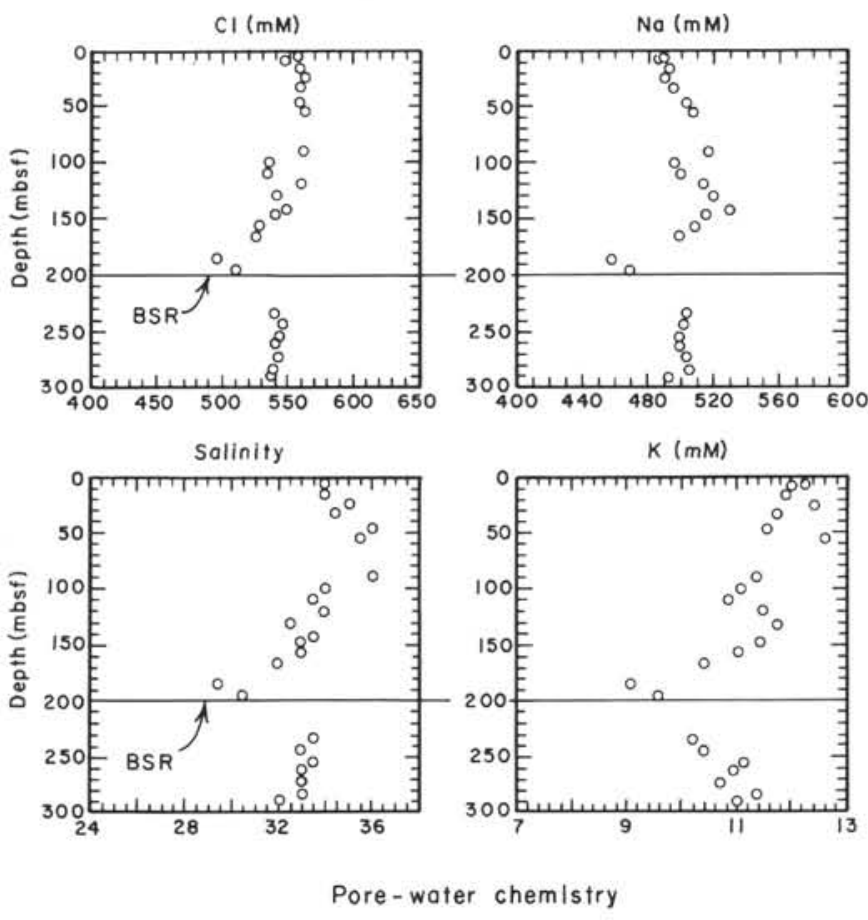

Figure 8. Vertical profiles at Site 860 of pore-water concentrations of chloride $\left(\mathrm{Cl}^{-}\right)$, sodium $\left(\mathrm{Na}^{+}\right)$, potassium $\left(\mathrm{K}^{+}\right)$, and salinity. Logging was unsuccessful at Site 860. Pore-water freshening occurs in the interval between 170 and 200 mbsf, just above the BSR. There was no core recovery in the 30-m-thick interval below the BSR. Lines and symbols are defined in Figure 7.

freshening. The gas hydrate within the two intervals apparently is finely disseminated and occupies less than $25 \%$ of the pore space. The source of the methane for gas-hydrate formation at this site is enigmatic. The very low TOC $(<0.5 \%)$ provides only a marginal in-situ source of methane for gas-hydrate formation. However, carbon-isotopic measurements support an in-situ source, with only minor contributions of methane from some external source. The processes involved in gashydrate formation at this site are evidently complicated by the complex thermal regime and fluid migrations associated with ridge spreading and subduction at the Chile Triple Junction.

Evidence for gas hydrate at Site 860 is less compelling than at Site 859. A strong BSR occurs at $200 \mathrm{mbsf}$ at Site 860 , and pore-water freshening is observed in the 20 - to $50-\mathrm{m}$ interval above the BSR. This site was not successfully logged. Nevertheless, the seismic and geochemical evidence is consistent with gas-hydrate occurrence. Only a very weak BSR occurs at Site 861 at about $250 \mathrm{mbsf}$, but no porewater freshening was observed above the BSR, and so gas hydrate is probably absent at this site.

\section{ACKNOWLEDGMENTS}

We thank the shipboard technical staff for their help in obtaining samples.

\section{REFERENCES}

Bangs, N., Cande, S.C., Lewis, S.D., and Miller, J., 1992. Structural framework of the Chile Margin at the Chile Ridge collision zone. In Behrmann, J.H., Lewis, S.D., Musgrave, R.J., et al., Proc. ODP, Init. Repts., 141: College Station, TX (Ocean Drilling Program), 11-21.

\footnotetext{
Abbreviations for names of organizations and publications in ODP reference lists follow the style given in Chemical Abstracts Service Source Index (published by American Chemical Society).
} 
Bangs, N.L.B., Sawyer, D.S., and Golovchenko, X., 1993. Free gas at the base of the gas hydrate zone in the vicinity of the Chile Triple Junction. Geology, 21:905-908.

Behrmann, J.H., Lewis, S.D., Musgrave, R.J., et al., 1992. Proc. ODP, Init. Repts., 141: College Station, TX (Ocean Drilling Program).

Cande, S.C., Leslie, R.B., Parra, U.C., and Hobart, M., 1987. Interaction between the Chile Ridge and Chile Trench: geophysical and geothermal evidence. J. Geophys. Res., 92:495-520.

Claypool, G.E., and Kaplan, I.R., 1974. The origin and distribution of methane in marine sediments. In Kaplan, I.R. (Ed.), Natural Gases in Marine Sediments: New York (Plenum), 99-139.

Claypool, G.E., and Kvenvolden, K.A., 1983. Methane and other hydrocarbon gases in marine sediment. Annu. Rev. Earth Planet. Sci., 11:299-327.

Fuex, A.N., 1977. The use of stable carbon isotopes in hydrocarbon exploration. J. Geochem. Explor., 7:155-188.

Harrison, W.E., Hesse, R., and Gieskes, J.M., 1982. Relationship between sedimentary facies and interstitial water chemistry of slope, trench, and Cocos plate sites from the Middle America Trench transect, active margin off Guatemala, Deep Sea Drilling Project Leg 67. In Aubouin, J., von Huene, R., et al., Init. Repts. DSDP, 67: Washington (U.S. Govt. Printing Office), 603-614.

Hesse, R., and Harrison, W.E., 1981. Gas hydrates (clathrates) causing pore water freshening and oxygen isotope fractionation in deep-water sedimentary sections of terrigenous continental margins. Earth Planet. Sci. Lett., 55:453-462.

Hesse, R., Lebel, J., and Gieskes, J.M., 1985. Interstitial water chemistry of gas-hydrate-bearing sections on the Middle America Trench slope, Deep Sea Drilling Project Leg 84. In von Huene, R., Aubouin, J., et al., Init. Repts. DSDP, 84: Washington (U.S. Govt. Printing Office), 727-737.

Jenden, P.D., and Gieskes, J.M., 1983. Chemical and isotopic composition of interstitial water from Deep Sea Drilling Project Sites 533 and 534. In Sheridan, R.E., Gradstein, F.M., et al., Init. Repts. DSDP, 76: Washington (U.S. Govt. Printing Office), 453-461.

Kvenvolden, K.A., 1993. Gas hydrates: geological perspective and global change. Rev. Geophys., 31:173-187.

Kvenvolden, K.A., and Barnard, L.A., 1983. Gas hydrates of the Blake Outer Ridge, Site 533, Deep Sea Drilling Project Leg 76. In Sheridan, R.E., Gradstein, F.M., et al., Init. Repts. DSDP, 76: Washington (U.S. Govt. Printing Office), 353-365.

Kvenvolden, K.A., Frank, T.J., and Golan-Bac, M., 1990. Hydrocarbon gases in Tertiary and Quaternary sediments offshore Peru-results and compari- sons. In Suess, E., von Huene, R., et al., Proc. ODP, Sci. Results, 112: College Station, TX (Ocean Drilling Program), 505-515.

Kvenvolden, K.A., Golan-Bac, M., McDonald, T.J., Pflaum, R.C., and Brooks, J.M., 1989. Hydrocarbon gases in sediment of the Vøring Plateau, Norwegian Sea. In Eldholm, O., Thiede, J., Taylor, E., et al., Proc. ODP, Sci. Results, 104: College Station, TX (Ocean Drilling Program), 319-326.

Kvenvolden, K.A., and Kastner, M., 1990. Gas hydrates of the Peruvian outer continental margin. In Suess, E., von Huene, R., et al., Proc. ODP, Sci. Results, 112: College Station, TX (Ocean Drilling Program), 517-526.

Kvenvolden, K.A., and McDonald, T.J., 1985. Gas hydrates of the Middle America Trench-Deep Sea Drilling Project Leg 84. In von Huene, R., Aubouin, J., et al., Init. Repts. DSDP, 84: Washington (U.S. Govt. Printing Office), 667-682.

Ocean Drilling Program, 1986. Guidelines for pollution prevention and safety. JOIDES J., 12 (Spec. Iss. 5).

Rice, D.D., and Claypool, G.E., 1981. Generation, accumulation, and resource potential of biogenic gas. AAPG Bull., 65:5-25.

Shipboard Scientific Party, 1992a. Explanatory notes. In Behrmann, J.H., Lewis, S.D., Musgrave, R.J., et al., Proc. ODP, Init. Repts., 141: College Station, TX (Ocean Drilling Program), 37-71.

, 1992b. Site 859. In Behrmann, J.H., Lewis, S.D., Musgrave, R.J., et al., Proc. ODP, Init. Repts., 141: College Station, TX (Ocean Drilling Program), 75-157.

, 1992c. Site 860. In Behrmann, J.H., Lewis, S.D., Musgrave, R.J., et al., Proc. ODP, Init. Repts., 141: College Station, TX (Ocean Drilling Program), 159-238.

, 1992d. Site 861. In Behrmann, J.H., Lewis, S.D., Musgrave, R.J., et al., Proc. ODP, Init. Repts., 141: College Station, TX (Ocean Drilling Program), 239-299.

Shipley, T.H., Houston, M.H., Buffler, R.T., Shaub, F.J., McMillen, K.J., Ladd, J.W., and Worzel, J.L., 1979. Seismic evidence for widespread possible gas hydrate horizons on continental slopes and rises. AAPG Bull., 63:2204-2213.

Date of initial receipt: 16 August 1993

Date of acceptance: 9 February 1994

Ms 141SR-019 